Published December 2019

EKONOMIKAWAN : Jurnal IImu Ekonomi dan Studi Pembangunan

ISSN : 1693-7600 (Print), ISSN : 2598-0157 (Online), http://jurnal.umsu.ac.id/indexphp/ekawan

\title{
Deteksi Sidik Jari Sebagai Inovasi Guna Medukung Keunggulan Bersaing Perajin Batik di Kabupaten Cirebon
}

\author{
Farida Yuliaty $^{1 *}$, Fitri Sya'bandyah ${ }^{2}$ \\ ${ }^{1}$ Program Studi Magister Manajemen, ${ }^{2}$ Program Studi Teknik Informatika \\ Universitas Sangga Buana YPKP Bandung, Indonesia \\ Jln. PHH.Mustopa No.68 Bandung \\ *e-mail : Fys.2207@gmail.com
}

\begin{abstract}
ABSTRAK
Batik adalah pakaian nasional yang memiliki peran strategis yang dapat menjadi alat yang dapat menggerakan perekonomian negara, peninggalan dan ciri budaya bangsa juga sebagai ciri khas bangsa. Terdapat tiga masalah utama yang sering dikeluhkan oleh industri batik, pertama, bagi Pengusaha sering terjadinya kenaikan bahan dasar pembuatan batik, dimana harga naik lebih cepat dibanding harga jual batik itu sendiri. Kedua masuknya produk tekstil dengan motf batik khususnya dari China dan ketiga sulitnya merekrut sumber daya manusia yang memiliki keterampilan membatik yang inovatif, serta memiliki kemampuan yang capable dalam pengembangan industri batik. Tujuan penulisan artikel pengabdian kepada masyarakat ini adalah mendekripsikan pentingnya inovasi keunggulan bersaing untuk menghadapi persaingan gobal serta merancang suatu aplikasi deteksi sidik jari untuk mendapatkan tenaga kerja (pembatik) terpilih guna mendukung keunggulan bersaing para pengrajin batik. Teknik analisis yang digunakan adalah analisis deskripsi yang menggambarkan kondisi industri batik, pengembangan inovasi yang mampu mengaplikasikan finger print test sebagai upaya menggali potensi para pengrajin batik. Hasil penelitian adalah adanya suatu aplikasi yang diharapkan dapat digunakan oleh pengusaha batik berupa deteksi sidik jari sebagai salah satu inovasi penetapan perekrutan sumber daya manusia (pengrajin batik) guna mendukung keunggulan bersaing.
\end{abstract}

Kata Kunci : Sidik Jari, Inovasi, Keunggulan bersaing 


\title{
Fingerprint Detection as an Innovation to Support the Competitive Advantages of Batik Crafters in Cirebon Regency
}

\begin{abstract}
Batik is national clothing that holds strategic on national economy development, cultural heritage, and diplomacy media between nations. There are three main problem that existed among the batik industries. First for the entrepreuneur, facing the rising price batik material, mori fabric that rises faster than price pf batik itself. Second, a huge wave of garment product from china and third is company hardly find a batik crafter that innovative, and have capable skill in batik industry development. The purpose of this research as a devotion to society are, describing the importance of innovation and competitive advantage to face global trading also designing fingerprint detection application to obtain a choosen employee (batik crafter) to gain competitive advantage among batik crafter. Analysis techinuque that used is descriptive analysis that visualize conditions of batik industry, innovation development that appting fingerprint test as an effort to discover batik crafters potencial. The result are that the application can be used in batik industry as a fingerprint detection, as a qualification on human resources recruitment (batik crafters) in order to development competitive advantage
\end{abstract}

Keyword : Fingerprint, Inovation, Competitive Advantage

\section{PENDAHULUAN}

Industri Batik menghadapi dua masalah yang seringkali dikeluhkan, yaitu berkaitan dengan derasnya produk tekstil dengan motif batik khususnya yang berasal dari China serta terbatasnya sumber daya manusia potensial yang memiliki kemampuan dalam pembuatan batik. Maka diperlukan bagi organisasi pelaku usaha IKM/UKM batik melakukan pengembangan bukan hanya menitikberatkan pada pengembangan UKM/IKM saja, tetapi idealnya diikuti dengan peningkatan kemampuan SDM (Sumber Daya Manusia) disegala bidang. Pengembangan mutu kerja SDM dibutuhkan utamanya meliputi kompetensi SDM, seperti knowledge, skill dan ability serta attitude dalam setiap usaha. Upaya pengembangan SDM selayaknya diupayakan pada semua unsur yang terlibat dalam IKM/UKM dan bukan hanya ditujukan pada pemilik usaha saja, melainkan juga pada seluruh pekerjanya.

Organisasi yang sukses adalah setiap organisasi yang senantiasa menciptakan dan membentuk pengetahuan yang menyeluruh dengan konsisten serta menyebarkannya secara cepat dan mampu beradaptasi dengan perubahan teknologi dan mampu bersaing untuk jangka waktu yang panjang. Dibutuhkan suatu sistem atau konsep untuk setiap informasi merupakan hal yang bernilai tambah dan memiliki nilai untuk menjadi sebuah pengetahuan bagi organisasi atau perusahaan. 


\section{Published December 2019}

EKONOMIKAWAN : Jurnal IImu Ekonomi dan Studi Pembangunan

ISSN : 1693-7600 (Print), ISSN : 2598-0157 (Online), http://jurnal.umsu.ac.id/indexphp/ekawan

Upaya untuk mendapatkan keunggulan dalam bersaing dapat dilakukan dengan inovasi, inovasi lahir karena adanya kemampuan perusahaan menciptakan pengetahuan, sehingga melahirkan daya saing. IKM/UKM di Indonesia belum memiliki keunggulan bersaing yang tinggi, hal ini disebabkan masih rendahnya daya saing yang dimiliki sehingga menyebabkan sulitnya IKM/UKM untuk maju, namun demikian ditengah kondisi ekonomi yang belum membaik dari krisis yang melanda dunia, IKM/UKM masih mampu bertahan dibandingkan perusahaan besar. Bahkan telah mampu memberikan kontribusi yang berarti bagi Pendapatan Domestik Bruto.

Cara yang dapat dilakukan untuk meningkatkan keunggulan bersaing dibidang usaha batik yang ada di provinsi Jawa Barat, khususnya kabupaten Cirebon. dapat ditempuh dengan mengintensifkan, membentuk dan menemukan inovasi guna meningkatkan daya saing industri batik. Salah satu upaya untuk menggali inovasi pengetahuan tacit melalui finger print test. Untuk maksud tersebut Pemerintah kabupaten Cirebon khususnya para pengusaha batik (pemilik/owner) perlu menyusun pengembangan pengetahuan (tacit dan eksplisit) dan inovasi, yang bermanfaat bagi peningkatan daya saing dan potensi industri batik kota Cirebon.

Rumusan Masalah :

1. Bagaimana inovasi dan keunggulan bersaing pelaku IKM/UKM Batik Cirebon ?

2. Bagaimana inovasi meningkatkan keunggulan bersaing IKM/UKM Batik Cirebon ?

3. Sejauh mana aplikasi fingerprint bermanfaat sebagai upaya menggali potensi calon perajin batik ?

Adapun Tujuan pengabdian ini adalah sebagai berikut :

1. Mendeskripsikan pentingnya inovasi dan keunggulan bersaing untuk menghadapi persaingan global.

2. Merancang suatu aplikasi deteksi sidik jari untuk mendapatkan tenaga kerja (pembatik) terpilih guna mendukung keunggulan bersaing para perajin Batik.

\section{KAJIAN TEORI}

Laurensius (2013:103) dan Damanpour (dalam Henry, 2005), mendefinisikan inovasi merupakan penciptaan gagasan baru atau adopsi sesuatu yang baru dapat dikatakan sebagai inovasi jika dikomersialisasikan menjadi produk atau jasa yang berkualitas dengan biaya yang lebih rendah dan berimprovisasi produk dengan atribut baru. Inovasi organisasi menurut Damanpour (dalam Hanny,2005) merupakan adopsi ide atau perilaku baru dalam organisasi. Inovasi adalah sistem kegiatan organisasi yang melakukan transformasi teknologi mulai dari ide hingga komersialisasi. Suatu alasan inovasi diperlukan karena terjadinya percepatan dalam lingkungan bisnis yang dinamis.

Inovasi (Lee, et.al, 2005) dibagi menjadi dua kategori yaitu inovasi administratif dan inovasi produk. Inovasi produk dalam perusahaan manufaktur misalnya sumber daya yang digunakan dalam kegiatan riset dan pengembangan (R \& D) perusahaan, seperti: fasilitas dan tenaga ahli teknis yang dipekerjakan, sedangkan inovasi administrasi meliputi perubahan dalam struktur dan proses manajerial. Dalam hal ini meliputi kemampuan perusahaan dalam menentukan bentuk dan proses yang dapat menyebabkan meningkatnya kemampuan penggunaan peluang internal baru (pengembangan teknologi baru) serta peluang ekternal berupa perluasan pasar baru. 
Menurut Damapour (2005) menambahkan jenis inovasi yang ketiga, yaitu Inovasi proses, yang menggambarkan perubahan dalam cara organisasi, memproduksi produk atau jasa akhir dari suatu perusahaan. Inovasi proses ini juga dapat menggambarkan perubahan dalam cara organisasi, memproduksi produk atau jasa akhir dari suatu perusahaan. Inovasi proses ini jaga mencakup tahapan dari produk baru, jasa atau pengembangan proses dari konsepsi gagasan dengan penerimaan di pasar (Perez, Cooper, 2005, et.al.).

Keunggulan sering diartikan sebagai melebihi batas atas standar dan menjadi superior. Keunggulan adalah tentang berusaha keras secara berkelanjutan untuk menjadi yang terbaik (the best), menjadi yang pertama (the first) dan menjadi yang berbeda (being different) di tempat pekerjaan dan di pasar serta di setiap cara yang mungkin (Victor S.L Tan, 2002).

Keunggulan bersaing sebagai keunggulan atas pesaing yang didapatkan dengan menyampaikan nilai pelanggan yang lebih besar, melalui harga lebih murah atau dengan menyediakan lebih banyak manfaat yang sesuai dengan penetapan harga yang lebih tinggi. Keunggulan bersaing adalah adanya keinginan manajemen yang kuat untuk menguasai : (1) biaya (cost), (2) mutu (quality), (3) waktu (time), dimana pencapain nilai pelanggan dalam rangka untuk memciptakan dan mempertahankan keunggulan bersaing erat hubungannya dengan aktivitas-aktivitas yang dilakukan oleh perusahaan.

Keunggulan bersaing perusahaan dapat dicapai dan bertahan bila perusahaan tersebut memiliki keunggulan sumber daya, khususnya sumber daya manusia. Pengelolaan sumber daya manusia adalah skala prioritas dalam kegiatan bisnis, dimana pergerakan roda pembangunan bisnis dilaksanakan oleh sumber daya manusia, mulai dari perencanaan sampai pada tujuan yang dicapai yang mampu memberi nilai baik bagi pelanggan maupun bagi perusahaan. Untuk mendapatkan karyawan yang unggul banyak perusahaan menerapkan praktik-praktik sumber daya manusia agar memiliki keunggulan dalam bersaing sehingga mampu menghasilkan produk yang bermutu sesuai permintaan dan harapan konsumen melalui bekerja secara efisien, sehingga tercipta biaya produksi yang murah.

Tujuh point pengimplementasian mencapai keunggulan bersaing, yaitu: 1) keselamatan kerja, 2) keselektifan dalam rekrutmen (selective in recruiting), 3) Desentralisasi dan Tim Swa Kelola, 4) tingkat upah yang tinggi, 5) Pelatihan (training), 6) mengurangi perbedaan status, dan 7) Information Sharing. Sumber daya yang unggul dan core competence (meliputi pegawai yang trampil, teknologi, informasi dan inovasi) adalah sumber nyata dari keunggulan bersaing sepanjang digunakan dan diselenggarakan dengan cara yang produktif.

Sistem mengandung arti sebagai kumpulan-kumpulan dari komponen-komponen yang dilmiliki unsur keterkaitan antara satu dengan yang lainnya. (Indrajit, 2001;220), yang berinteraksi untuk mencapai suatu tujuan tertentu (Jogianto, 2005;2)

\section{METODE}

Metode yang digunakan adalah metode survei, yaitu penelitian yang dilakukan terhadap suatu populasi dengan metode sampel yang mewakili populasi tersebut. Teknik yang digunakan yaitu dengan kombinasi tiga teknik yaitu, kuisioner, wawancara dan observasi. 
Metode analisis yang digunakan adalah analisis deskriptif, yang menggambarkan kondisi nyata untuk setiap variabel di lapangan. Disamping secara deskripsi di atas, peneliti juga menyusun suatu program untuk dapat menentukan karakteristik calon karyawan (pengrajin batik).

\section{Metode Analisis Fingerprint}

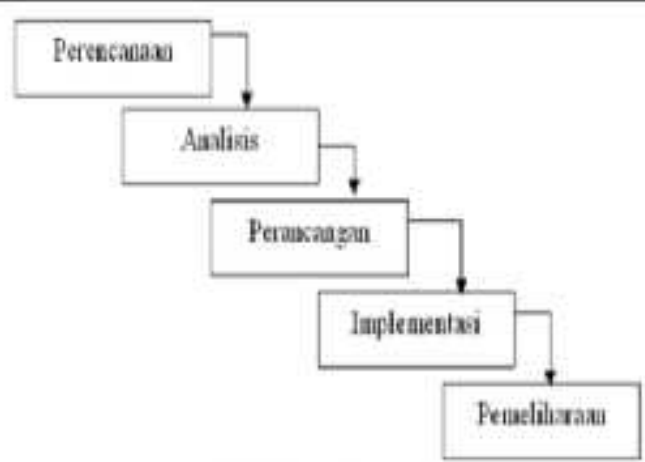

Model Hiaterfatil

Gambar 1: Model Waterfall

Dalam rangka efisiensi perancangan ini dibuat untuk dapat diaplilkasikan pada handphone android yang memiliki spesifikasi fingerprint. Kemudian hasil dari fingerprint tersebut dicocokkan sebagai salah satu proses administrasi rekrutmen.

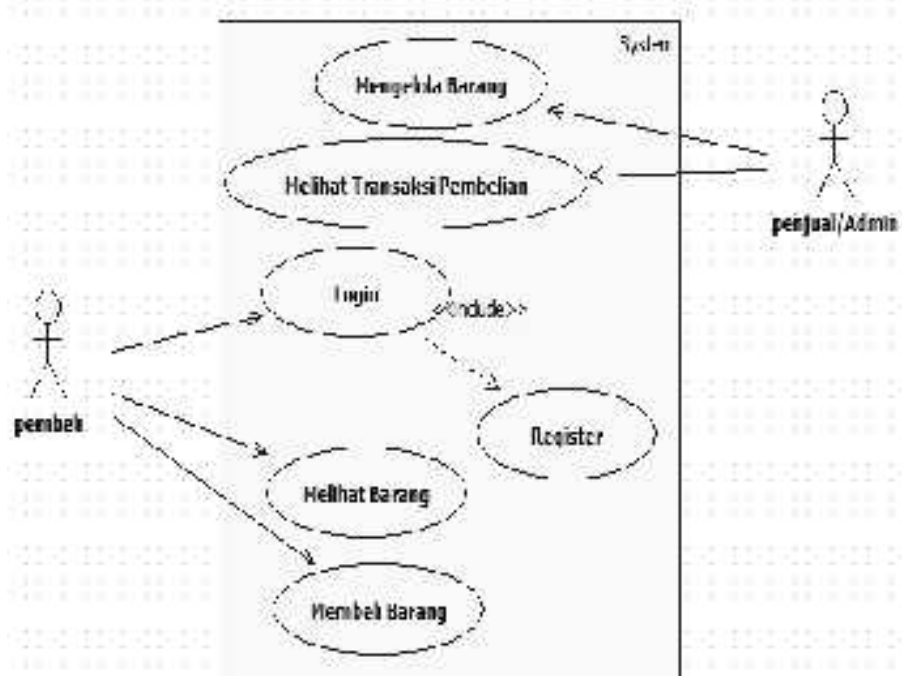

Gambar 2: Contoh Use Case Diagram

Dalam penelitian dilakukan pengamatan dasar pola sidik jari, sehingga diharapkan ketika aplikasi dibuat dapat membantu proses yang mendukung penentuan calon karyawan. 
Published December 2019

EKONOMIKAWAN : Jurnal IImu Ekonomi dan Studi Pembangunan

ISSN : 1693-7600 (Print), ISSN : 2598-0157 (Online), http://jurnal.umsu.ac.id/indexphp/kkawan

\section{HASIL DAN PEMBAHASAN}

Rekapitulasi Means Score Jawaban Koresponden.

Tabel 1. Jawaban Koresponden

\begin{tabular}{|l|l|c|l|}
\hline \multirow{4}{*}{ Variabel } & \multicolumn{1}{|c|}{ Indikator } & $\begin{array}{c}\text { Mean } \\
\text { Skor }\end{array}$ & \multicolumn{1}{c|}{ Kirteria } \\
\hline \multirow{3}{*}{$\begin{array}{l}\text { Kemampuan } \\
\text { Inovasi }\end{array}$} & Inovasi produk & 3,57 & Cukup Baik \\
\cline { 2 - 4 } & Inovasi proses & 3,72 & Cukup Baik \\
\cline { 2 - 4 } & Inovasi administrasi & 3,22 & Cukup Baik \\
\cline { 2 - 4 } & Grand Mean & $\mathbf{3 , 5 1}$ & Cukup Baik \\
\hline \multirow{3}{*}{$\begin{array}{l}\text { Keunggulan } \\
\text { Bersaing }\end{array}$} & Bernilai & 3,50 & Cukup Tinggi \\
\cline { 2 - 4 } & Kompetensi & 3,46 & Cukup Tinggi \\
\cline { 2 - 4 } & Inimitate & 3,65 & Cukup Tinggi \\
\cline { 2 - 4 } & Tidak tergantikan & 3,85 & Cukup Tinggi \\
\cline { 2 - 4 } & Grand Mean & $\mathbf{3 , 6 2}$ & Cukup Tinggi \\
\hline
\end{tabular}

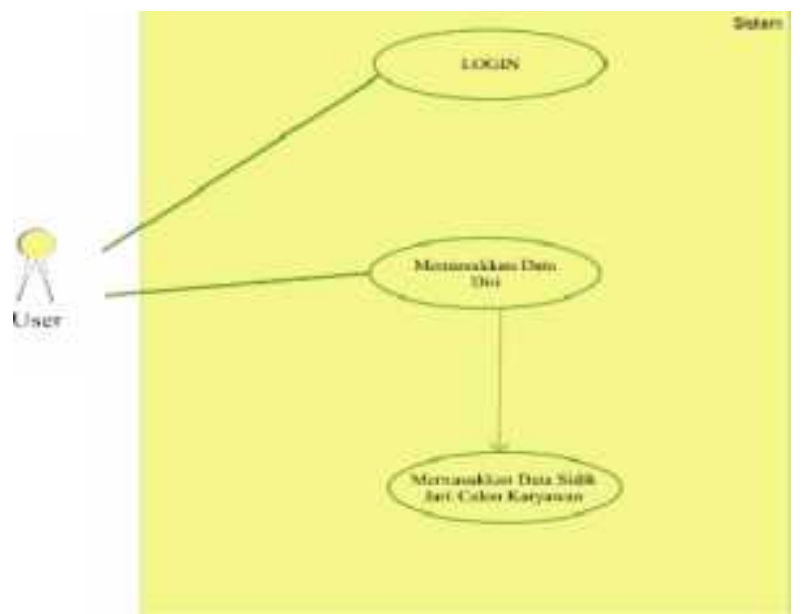

Gambar 3. Use Case

\section{PEMBAHASAN}

\section{Analisis Sistem Berjalan}

Finger Print dewasa ini sangat banyak digunakan oleh instansi atau perusahaan baik kecil, menengah dan bahkan perusahaan besar, bahkan sebagai presensi perorangan, identitas diri sebagai administrasi, juga identitas pengenal diri pada perangkat tertentu seperti smartphone, bahkan dibeberapa instansi swasta tidak jarang menggunakan finger print sebagai akses masuk antar ruangan yang diterapkan pada kunci pintu. Setelah calon karyawan diwawancara, diwajibkan untuk melakukkan pengisian data berupa data diri.

Setelah melalui proses tersebut maka calon karyawan akan diberitahukan lebih lanjut mengenai diterima tidaknya sebagai tenaga kerja pembatik.

Proses Bisnis Sistem, dilakukan sebagai berikut:

1. Pengisian Formulir, setiap calon karyawan yang akan mendaftarkan diri sebagai pengrajin batik di perusahaan diwajibkan mengisi setiap formulir sesuai data diri. 
2. Proses wawancara, setelah calon karyawan mengisi formulir maka setiap calon karyawan akan melalui proses wawancara oleh seseorang yang bertanggung jawab untuk proses wawancara.

3. Proses Scan Sidik Jari, setelah calon karyawan selesai dalam proses wawancara, calon karyawan diwajibkan untuk mengisi data dalam aplikasi sesuai data yang diisi saat pengisian formulir.

4. Penentuan penerimaan calon karyawan.
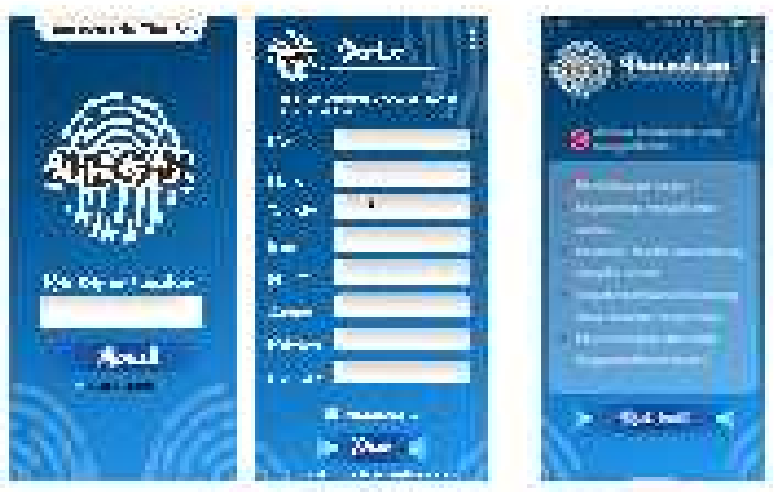

Gamba: Harl Sar da Culoh Hisi harlisa

Gambar 4. Hasil Scan dan contoh Hasil analisa

\section{SIMPULAN}

1. Kemampuan Inovasi para pengrajin batik cukup baik, dari segi inovasi produk, inovasi proses, maupun inovasi dalam pengadministrasian. Kemampuan inovasi produk paling kuat dalam merefleksikan kemampuan inovasi. kemudian disusul indikator Inovasi proses. Sebaliknya indikator Inovasi administrasi paling lemah dalam merefleksikan kemampuan inovasi.

2. Keunggulan bersaing dari pengrajin batik di Cirebon bernilai cukup tinggi, memiliki kompetensi cukup tinggi, inimitate dan ke tak tergantikan pun cukup tinggi, keunggulan bersaing yang dimiliki para pengrajin dalam melakukan proses hingga menghasilkan produk batikpun cukup tinggi.

3. Kemampuan inovasi akan memberikan pengaruh yang cukup kuat terhadap keunggulan bersaing IKM/UKM di Cirebon.

4. Dari hasil pengujian, aplikasi ini belum optimal karena masih dalam taraf pengembangan.

\section{DAFTAR PUSTAKA}

Adegoke Oke (2004), Barrier to Innovation Management is Service Company

Agus Mulyanto, 2009, Sistem Informasi Konsep dan Aplikasi, Pustaka Pelajar, Yogyakarta.

Azhar Susanto, (2013), Sistem Informasi Akuntansi, -Struktur-Pengendalian-. Edisi

9 Buku 2, Jakarta : Salemba Empat. 
Cooper, D.R, \& Schindler, P.S, (2014), Business Research Methodes (12 ${ }^{\text {th }}$ ed), International Edition, Mc Graww Hill.

Cummins, Harold (1943), Fingerprints Palms and Soles, Digital Library of India Item 2015,43762

Fakih Abdullah, et.al. (2015), Pemanfaatan Teknologi Fingerprint Authentication untuk Otomatisasi Presensi Perkuliahan, Journal of Information Systems Engineering and Business Intelligence Vol. 1, No. 2, October 2015.

Isobe, Montgomery (2008), Strategic Management Concept, Competitives and Globalization, USA.

Jerry Honeycutt (2000) Knowledge Management Strategies, Microsoft Press, USA.

Kaplan R.M and Saccozo (2005). Psychological Testing, Principles, Aplications. And Issues. $\left(6^{\text {th }}\right.$ ed.). Thomson Wadsworth, Belmont USA.

Muhamad Muslihudin, Oktafinao,(2016) Analisis dan Perancangan Sistem Informasi Menggunakan Model Terstruktur dan UML, Penerbit Andi.

Michael E Porter (2008), Competitive Advantage Creating and Sutaining Superior Performance, NY.

Peter F Drucker (2009), Harvard Business Review On Knowledge Management, Harvard Business School Press, USA.

Prefer, John Miner (2005), Organizational Behavior, From Theory to Practice, 4 New York.

Suyanto, M, Multimedia alat-alat untuk meningkatkan keunggulan bersaing.

The World Economic Forum (2005), A-Multi Stakeholder Approach to Global Governance.

Yung Shuan Chen dan Chin Chang Chen, 2009, A Model of Factors Moderating The Relationship Between New Product Development and Company.

Wang Jiang, et al (2008), Work And Organization in China After Thirty Years of Transition. 